\title{
近世・近代における富山城下の水路に関する研究 A STUDY ON DRAINAGE SYSTEM IN THE CASTLE TOWN OF TOYAMA DURING PRE-MODERN AND MODERN ERA
}

\author{
水田 恒 樹* \\ Tsuneki MIZUTA
}

\begin{abstract}
This study is to examine how Toyama, a castle town, harnessed the creeks which flew through the town, focusing on its drainage system. For this purpose, function, structure and construction process as well as storm water discharge of the system are examined. Resulted findings are as follows. 1) Water from irrigation system for farms on the back of the town flew into the creeks and increased the risk of flooding. 2) The major channel of the system was dug to detour the creeks around the town. 3) Storm water exceeding capacity of the major channel resulted floods of the creeks.
\end{abstract}

\section{Keywords : Castle town of Toyama, Drainage system, Pre-modern, Modern, Floods \\ 富山城下町，水路，近世，近代，水害}

\section{1. 研究の背景·目的·方法}

\section{(1) 近世都市の水路に関する既往の研究}

近世都市の水路 (用水) に関する既往研究を概観すると、水路の実 態や歴史では、渡部が多くの歷史的な都市用水を調查し1)、佐々木 らが松代城下町の水路網の変遷を絵図によって追跡した ${ }^{2)}$ 。

水路と都市との関係については、玉井らが金沢城下町における犀 川と辰巳用水の変遷や改修を詳細に論じ ${ }^{3)}$ 、後藤らが佐賀城下町の 水路や両岸の宅地などの空間を定量的に調查している4)。田中は近 世京都の三条・祇園地区における白川の流路変遷と、地区の農業や 鴨川の堤防建設に伴う市街化との関係を明らかにする一方 ${ }^{5)}$ 、舟運 のために開削された高瀬川が沿川の開発に与えた影響を論じた ${ }^{6)}$ 。

水路の社会的機能では、中岡が越前大野城下町において、町方と 侍屋敷・寺屋敷を隔てる役割、維持管理のルールに注目し、身分的 秩序、社会的秩序を空間化する装置と捉えた ${ }^{7)}$ 。

水路は河口、自然堤防帯、扇状地などの河川地形によって、勾配 や水流が大きく異なり、その起源も自然河川、農業用水、新規の開 削と多様である。また、当初は汽水域の排水と揚げ土確保のために 開削された近世大坂の堀川が、後世には舟運に使われたように、使 途も変化しうる ${ }^{8)}$ 。上記の研究はそれぞれ主題を限定しているが、 近世の水路の多面的な機能に鑑みて、都市の水文的な環境、水路の 必然性、整備の手法、その後の変化などを総合的に把握し、都市の 変容過程に位置づけることも重要と考えられる。

\section{(2) 研究の目的·方法}

世界屈指の急流常願寺川の扇状地、北陸の大河神通川の河畔に築 かれた富山町では、城下に及ぶ水害が 1580 年以降の 360 年間に 79 回を数える一方、近代の治水事業は土木史の金字塔である。筆者の
前研究では神通川と常願寺川に焦点を当て、近世と近代の富山城下 町について立地、土地利用、利水、治水、水害の相互関係を論じた が、現在も続く内水氾濫には言及しなかった ${ }^{9)}$ 。

本研究の目的は城下の水路に焦点を絞り、その形成過程、構成と 機能、接続する小河川の汇濫による影響を明らかにして、扇状地都 市における水系の制御について考察することにある。水路の形成過 程や構成は各時代の城下絵図、機能や水害に関しては史料や地誌の 分析を主たる方法とし、不足は行政資料や現地調查で補う。

なお、富山町とは近世の富山城下を指すが、本稿では町村合併で 拡大した近代の富山市においても、旧城下を富山町と呼称する。

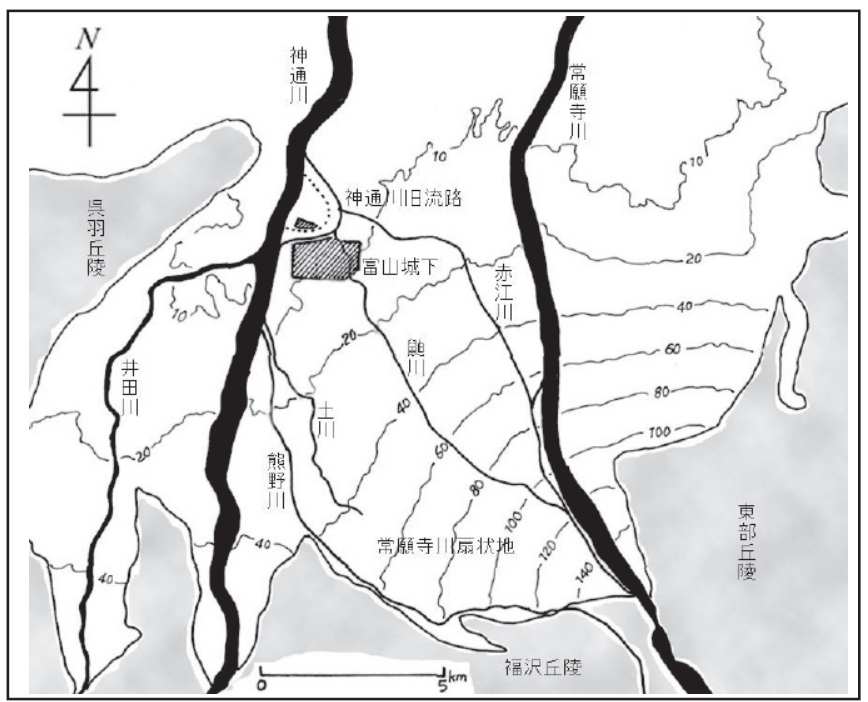

図1 富山町の河川環境(国土地理院、地形地域区分図より著者作成)

\footnotetext{
* 法政大学デザイン工学部建築学科 大学院生・医博・工修
}

Graduate Student, Dept. of Architecture, School of Design \& Engineering, Hosei University, Ph. D. in Med., M. Eng. 


\section{2. 富山町の河川環境亡歴史}

\section{(1) 河川環境}

常願寺川は急流で侵食力が強い。源流の立山カルデラは多雨豪雪 のうえ大量の崩壊土砂を排出し、常願寺川扇状地を形成した。水系 の河川群は首振り状の移動を繰り返し、扇面には放射状の河道跡が 無数に残る ${ }^{10)}$ 。城下の舀川は現存する派川のひとつである（図 1 )。 一方、飛騨高原の多雨地帯に発する神通川は、洪水時に強大な工 ネルギーを発揮し、呉羽丘陵と常願寺川扇状地の間を乱流してきた。 中世には常願寺川扇状地に押されて、呉羽丘陵の東麓を北流してい たが、戦国期に常願寺川扇状地に向かって東遷した ${ }^{11)}$ 。富山城はこ の時に形成された蛇行を要害としたため、城下は近世、近代を通じ て水害に苦しむ。この蛇行を解消寸る捷水路、地元で言う馳越 (はせ こし) 線は明治 34 年に着工、大正末期に完成した。旧河道は埋め立 てられて市街地となり、排水機能を担う松川が残される（図 2 ）。

\section{(2) 城と城下町の歴史}

富山城は天文 12 (1543) 年頃、神通川左岸から右岸に進出した神保 長職によって築かれ ${ }^{12)}$ 、その位置は近世富山城と重なることがほぼ 確認されている ${ }^{13)}$ 。慶長 10 (1605) 年、加賀藩の前田利長は富山に 隠居して中世城下町を作り直したが、 4 年後の大火で高岡に移る。 寛永 16 (1639) 年に加賀藩から独立した富山藩は、百塚に新城ができ るまでの間、遺棄された富山城を借用する。寛文元 (1661) 年に前田 利次は方針を変えて富山を居城とし、城下の再々整備に着手した。 これが現在の中心市街地の骨格となった近世富山町である ${ }^{14)}$

近世には船橋が渡り、水路がめぐって、水辺が賑わう個性的な都 市だったが、近代には神通川馳越線の開削、常願寺川の砂防や農業 用水の合口化など、土木史に残る治水事業によって洪水が制御され、 舟運の衰退も重なって河川と疎遠になった。戦後は多くの水路が道 路と化し、助作川のみが開渠として残る（図 2)。

\section{3. 水路網の形成過程}

(1) 近世初頭(17世紀前半)

現存最古の城下絵図「越中国富山古城之図」 ${ }^{15)}$ は、正保 4 (1647) 年の幕命により各大名が提出した、いわゆる正保城絵図の控えの可

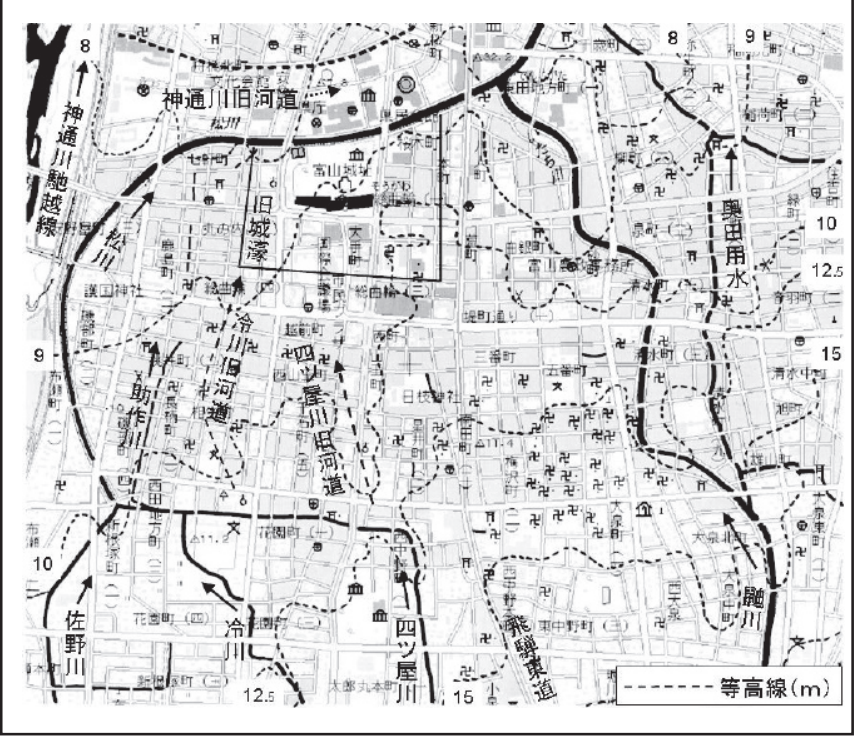

図2 城下の現況（国土基本図、治水地形分類図より著者作成）
能性が高い。借用中の城下を大規模に整備したとは考えにくいこと から、慶長期の富山城下の姿を留めるものとされる（図 3 )。

絵図には河川の名称がなく、後世の状況から判断すると東から川

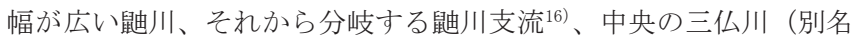
足洗川 ${ }^{17)}$ )、四ツ屋川 (旧名芋田川)、西端を北流する助作川である。 なお、当時の四ツ屋川は冷川と未分化のように見えるため、図中に は両名称を記した。街路と並行に流れて直角に屈曲し、流未が城濠 に接続するなど、人手が加わったような痕跡も散見されるが、細流 群が北北西に向から全体的な景観から、扇状地の地形や水系を概放 保存しつつ、格子状の城下町が作られたと推察できる。

越中では日本海岸を通る中世の北陸道に対し、近世の北陸街道は 内陸を通り、西の高岡から富山を経て、東北の水橋に至る。この絵 図では北西から町に入り、神通川を舟で渡って、兒川に沿って河口 から遡り、左折して町を東に出る近世の旧道と、慶長 10 (1605) 年に 架けられた船橋を渡り、富山城の西から南を迂回しながら城下を通 る新道が観察される。

街区の特異点に注目すれば、第一に旧道に沿う市街地は、格子状 の町割とは無縁に斜行しており、城下町以前の形成を窺わせる。第 二に城東地区は街区が大きく、図では省略しているが武家地、町人 地、寺院が混在し、古い地名や伝承が残ることから、ここに戦国期 の城下町があったものと考えられている ${ }^{18)}$ 。第三に飛騨東道は城南 地区の中央をやや西に傾いて縦断しているが、これは扇状地の自然 堤防の尾根に沿って形成されたためである。

\section{(2) 近世初期 (17 世紀後半)}

前田利次による城下整備が始まって間もない寛文 6 (1664) 年に描 かれたとされる「御調理富山絵図」19) では、正保絵図の自然河川群 に代わって人工的な水路網が形成されている。これに言及した史料 はないが、絵図から次のような構造が読み取れる（図 4)。

第一は城下の南辺に沿って東西方向に開削された水路で、幅も広 く城下を守る堀のようにも見えるため、仮に南堀と呼ぶ。前述のよ うに城下では飛騨東道が分水界となり、それ以西の南堀は西流する。

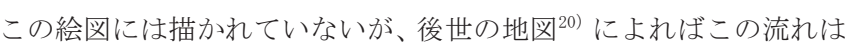
四ツ屋川、冷川、佐野川の水を集めて西の神通川に落ちており、主

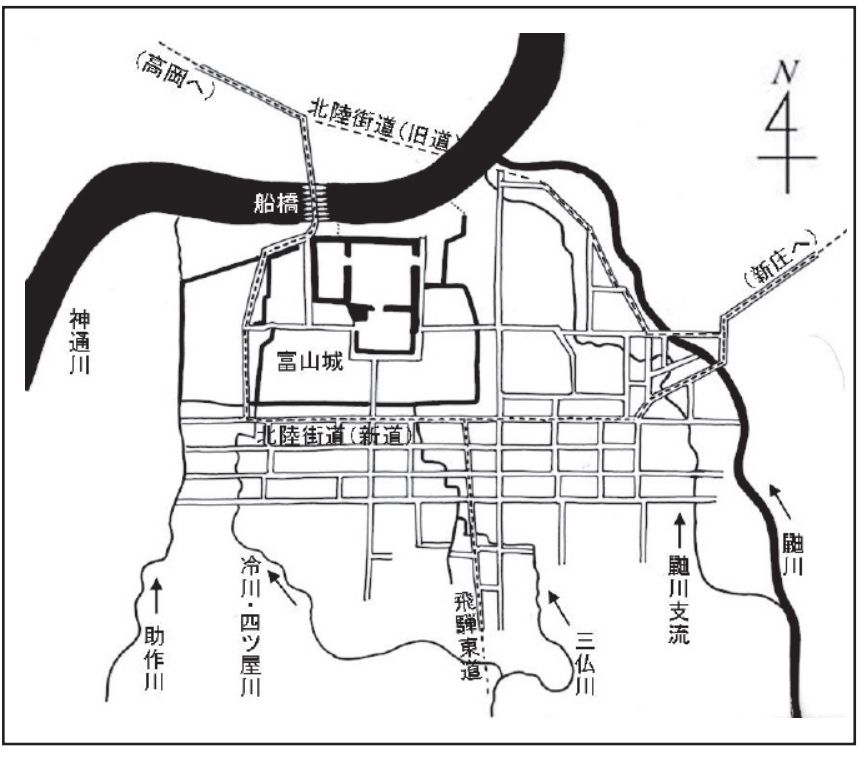

図3 17 世紀前半の水路網（「越中国富山古城之図」より著者作成） 


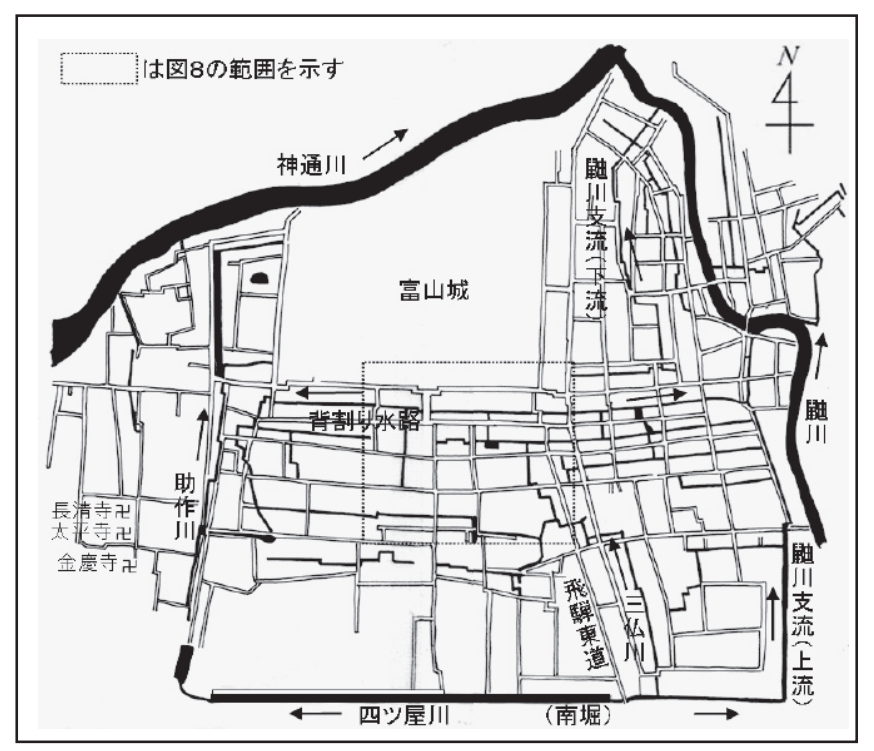

図4寛文 6 (1666)年の水路網（「御調理富山絵図」より著者作成）

たる水源から四ツ屋川と称されて現在に至る。飛騨東道以東の南堀 は、三仏川を水源として東流する。

第二は前節でみた 4 本の自然河川の改修である。まず、旧四ツ屋 川は瀬替えされ南堀西流と化したが、そこから水門で制御された一 定の水量が助作川に入り、北流して城濠に至る。同様に、三仏川の 水量の多くは南堀東流を経て臿川支流を北流し鼠川に落ちるが、一 部は水門で制御され従来からの自然流路を流れる。なお、源流を失 った舀川支流の下流部は、城東地区の排水路として残されている。

第三は東西方向に開削された複数の背割り水路で、三仏川を水源 とし飛騨東道以西は西流して助作川 、以東は東流して鼠川支流に 合流する。なお、背割り水路をつなぐ南北方向の水路も散見する。

\section{(3) 近世中期}

宝永 $2(1705)$ 年の城下絵図には、城西地区の助作川以西が描かれ ていない（図 5 )。これは神通川の水害常襲地が再建されず、農地化 したものと考えられる。図 4 で城西地区にあった 3 寺院が、図 5 で



図5 宝永 2 (1705) 年の水路網（「富山市街古図」より著者作成）

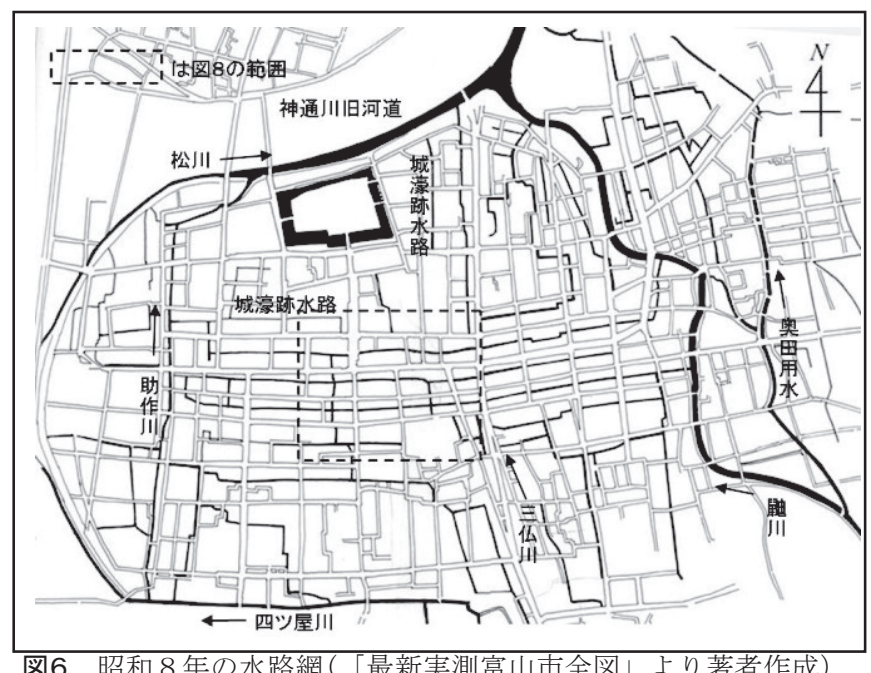

は城南地区にある。両図では宅地割りを省略したが、原図では下級 武士の組屋敷が、城西地区から城南地区南部の農地に移転している。

これを受け、城南地区南部では分散していた灌鿆水路を冷川旧河 道と見られる低地に集約し、大手通に面した藩蔵の周囲に堀を開削 している。この他、城東地区の城に近い上級武士の屋敷と町人町の 間に、南北方向の背割水路がつくられた。

なお、寛文 7 (1667) 年から宝暦 11 (1761) 年までの約百年間に、家 中は 7000 人台でほぼ一定だが、町方は 15000 人から 20000 人程度に 増加した ${ }^{21)}$ 。鼠川両岸では新たな街路が作られており、町方の人口 増は主としてこの地区に吸収されたものと考えられる。

(4) 近代

断続していた水路もほぼ繋がり、ネットワークが完成した(図 6 )。 すべての背割水路を導水幹線である三仏川に接続した点には、特に 注目すべきだろう。常時、水を流すことによって衛生状態を保ち、 融雪などにも使えることをめざしたものと思われる。

なお、明治維新以降、富山城域は本丸を残して官庁、学校、浄土 真宗両派の別院、遊里などの用地となったが22)、埋め戻した外堀の 内側に沿って排水路が巡っている。

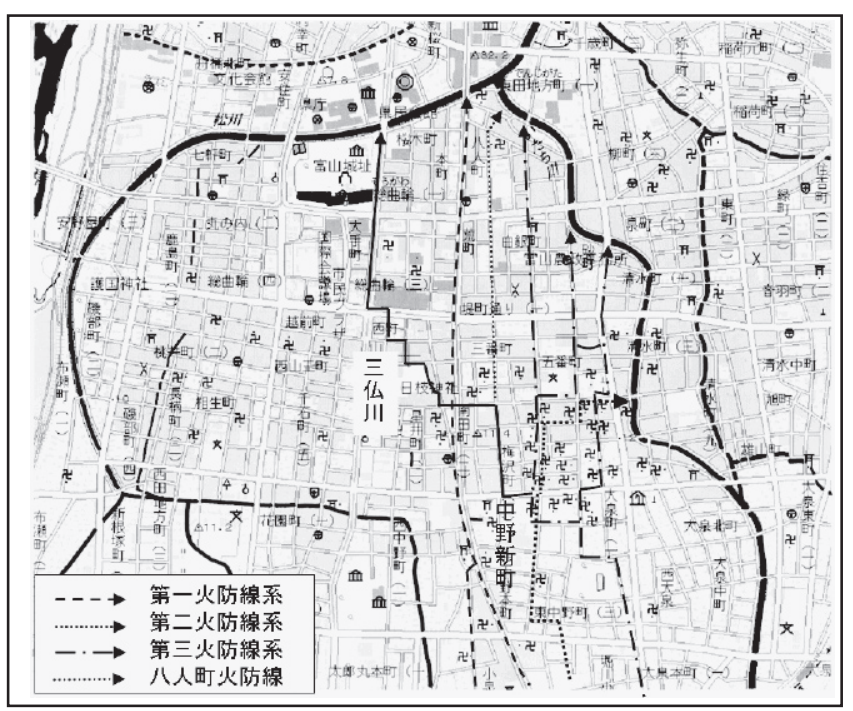

図7 火防水路（富山市建設部河川港湾課の資料により著者作成） 
また、幕末に計画されたが政情不安、藩の財政難から見送られた火 防水路が、6000 戸を焼いた明治 18 (1885) 年の大火後に実現した (図 7 )。すなわち、南郊の土川から取水し、飛騨東道に沿う幅 $1.8 \mathrm{~m}$ 、 深さ $1.5 \mathrm{~m}$ 、約 $2700 \mathrm{~m}$ の幹線水路で中野新町まで導き、そのまま北流 して神通川へ落ちる第一火防線、分岐後に寺町を縦断してから東流 乙臿川几落ちる第二火防線である。火防水路は多くが道路の拡幅と ともに整備され、明治 24 年の「家屋制限規則」による瓦屋根の推奨 とともに、総合的な都市防災に位置づけられていた。拡幅された近 代的な街路、中央を流れる水路の美観は市民に喜ばれたという ${ }^{23)}$ 。

その後、第三火防線や各線の分水などが寺町地区や城東地区に整 備された。なお、昭和 12 (1937) 年に都市計画決定された城西地区、 旧城内などにおける 5 条の火防水路は24)、いずれも事業化されてい ない。その後、消火栓の整備などに伴って火防水路は暗渠化された。

\section{4. 水路の仕組み}

城南地区を対象として、明治初期の水路図（図 8、範囲は図 4 6 に表示) から水路網の仕組みを、既出の寛文図 (図 4 )、宝永図 (図 5 )、昭和図（図 6 ）との比較から変化を考察する。便宜上、図 8 の 4 本の背割り水路を北から水路 $\mathrm{A} \sim \mathrm{D} 、 3$ 本の南北水路を西から水 路 $\mathrm{P} \sim \mathrm{R}$ と呼称し、各水路は数字 $1 \sim 4$ を添えて分節する。

(1) 図 8 の隅部の標高は、国土基本図によれば北西 $9 \mathrm{~m}$ 、北東 $10 \mathrm{~m}$ 、 南西 $11 \mathrm{~m}$ 、南東南 $12 \mathrm{~m}$ 程度である。つまり西より東、北より南が高 く、原則として南北水路は北へ、背割り水路は西へ流れる。

(2) 背割り水路は各宅地の排水を集める支線、南北水路は背割り水 路の排水を集める幹線である。ただし、水路網の最上流に位置する 東端の R 1 (三仏川) は、分岐後南流寸る R 2 とともに城下外から各 水路への給水幹線である。

(3) 背割り水路A $1 \sim 3 、$ B 3 5、D $1 \sim 2$ は近世初期の寛文図に描か れているが C 2 は明治図、 C 1 は昭和図から登場する。南北水路 $\mathrm{P} 1$ 、 Q 2、R1〜2 も寛文図にあるが P 2 は宝永図、Q 1 は明治図から登場 する。つまり水路網の外郭は早期に、他は徐々に整備された。

(4) 寛文図にあったB 3 が明治図では失われており、この状況下で B 4 は東に流さざるを得ない。また、近年行なわれた A 2 の発掘調 查では、流れの方向が逆の新旧 $2 つ の$ 水路が隣接して検出された ${ }^{25)}$ 。 つまり、背割り水路の勾配は水路網の改変に応じて変更された。

(5) 上記 $\mathrm{A} 2$ の改修は、幕末に開削された Q 1 に関わっていると考 える。それまで城濠の水は城西の助作川から供給されていたが、何 らかの事情でそれを補う必要が生じて、Q 1 経由でR 1 (三仏川)の 水を導入し、その結果として近傍の A 2 が反転したのではないか。 いずれにせよ、南北水路は城濠に給水する機能も有していた。

(6) 屎尿は肥料として城下から別途搬出されていたと考えられ、水 路網を流れるのは三仏川や助作川の河水、城下の湧水と雨水、主と して豊富な井水を使った後の生活排水である。

(7) 水路 $\mathrm{B}$ が 6 箇所で屈曲しているのは、水路以前からある町家の 敷地境界に合わせて開削されたためと考えられる。同じ町内でも北 側の水路 A は、寛文期に城濠沿いを武家地と寸る再配置が行なわれ たために屈曲がない26)。

(8) 現在も残る助作川、近代に作られた防火水路、発掘された水路 $\mathrm{A} 2$ の石組みなどから、水路の幅員は $1.8 \mathrm{~m}$ 程度と考えられる。

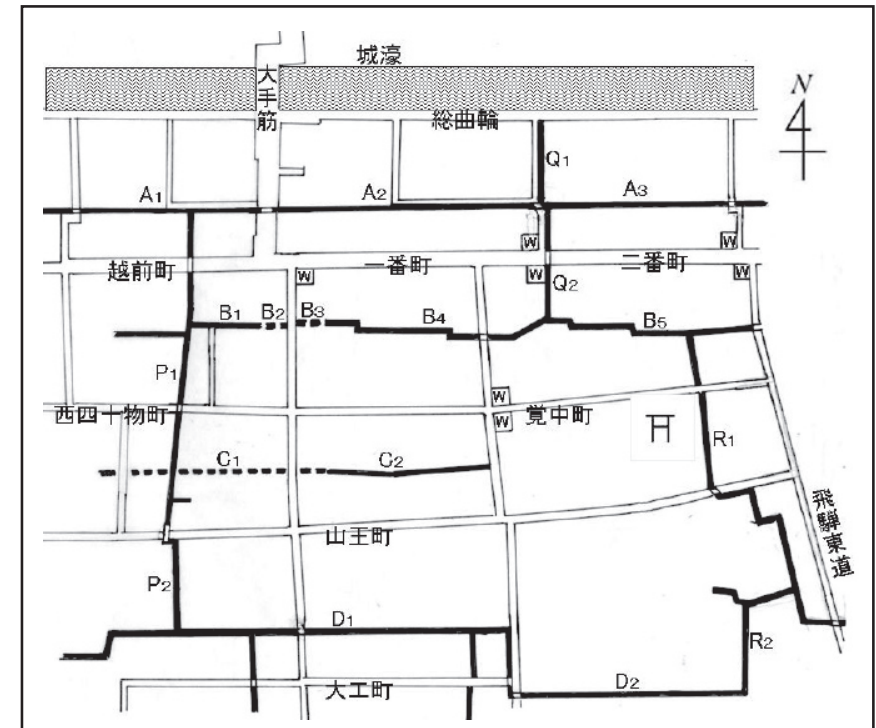

図8 明治 9 (1876) 年の水路図（各町地籍図より著者作成）

\section{5. 水路の目的と活用 \\ (1) 城下の防衛}

富山町中心部を三方の水路、南堀と助作川、鼠川支流が囲む構成 については、富山藩が最大の外様大名加賀前田家の支藩であり、幕 府の攻撃に備え城下に惣構を設定したとの説がある27)。

\section{(2) 融雪と作庭}

冬季の通行や輸送の確保のため、城下では除雪に関するルールが あった。屋根の積雪は前屋根分を街路に、後屋根分を宅地におろす のが原則で、裏庭に雪を捨てる空地を残すことが義務付けられ、背 割り水路は裏庭の融雪機能も担っていた。街路では侍屋敷、町屋を 問わず除雪を一斉に行ない、雪塊を空地、田畑、川、水路に運んで 捨てた。必要に応じ、城の堀に捨てることも許されたという。

富裕な町屋には通り庭があり、前面道路の雪を裏庭へ運ぶために 使われた。また、城下にすぐれた庭園や露地が数多く見られたのも、 裏庭や水路の存在が深く関わっている ${ }^{28)}$ 。

\section{(3) 水車}

扇状地の高低差を背景に、水車の利用も活発だった。複数の絵図 には、西南の郊外、四ツ屋川と佐野川の合流点付近に塩硝蔵と番人 小屋が記載されている ${ }^{29}$ )。加賀藩では収入源として塩硝 (火薬)の製 造を重視し、硝石、硫黄、炭を粉砕する水車薬合所を辰巳用水沿い に設けた。材料は加賀藩に属していた冨山県五箇庄から、塩硝街道 を通って運ばれていたという30)。富山藩でも水量が安定して豊かで、 爆発事故が城下に及ばない立地が選ばれたものと考えられる。

民間施設では、天保頃の鼠川の絵図に「搗屋」と記された 4 軒の 水車小屋が描かれている ${ }^{31)}$ 。地元で「かっちゃ」と呼ばれた水車小 屋は精米、漢方薬原料や菜種の粉砕、綿打ちなどに特化して数多く 存在した。これらの木造水車は、大正期に冨山県で発明されて爆発 的に普及した螺旋水車に代わられ、それは電動機が一般化する 1950 年代まで続く $\left.{ }^{32)} 33\right)$ 。なお、これらの水車は鼠川ではなく、そこに流 入する三力村用水や東田地方用水の水力を利用している。

\section{(4) 防火}

富山町は繰り返し大火に見舞われたが、近世において水路の水を 消火に使ったという記録はない。文化元 (1804) 年の火災の後、藩は 
用心井戸の設置を命じ、30 か町が 32 箇所で通り沿いの町屋の軒下 に井戸を掘り、釣瓶と竜吐水（手押しポンプ）を整備した。天保 12 (1841) 年には 29 か町の 42 箇所に増えている ${ }^{34)}$ 。図 8 で四つ辻に 表示したWがそれである。このことから、藩政期につくられた水路 は、配置や水量などの点で消火の用には耐えなかったものと考えら れる。近代の防火水路については既述した。

\section{6. 水路の氾濫}

河川と水路の水害は同時に起きることが多く判別しがたいが、神 通川の水位が 10 丈余に達しながら、危うく破堤を免れた事例が記録 に残っている。水害の原因は「溝渠涱溢」とされ、城下の 11 町に浸 水被害があった ${ }^{35)}$ 。それを地図上にプロットしたところ、城西地区 の被災 4 町は助作川に沿っているが、城南地区 7 町は三仏川よりも やや西寄りに分布する（図 9 )。これは四ツ屋川が溢水し、その旧河 道を流れたものと考えられる。四ツ屋川は前述のように瀬替えされ たが、旧流路は現在も低地である（図 2 の等高線参照）。

馴越線完成後は神通川の破堤がなくなり、水路の汇濫が顕在化す る。図 10 の事例では七軒町用水 (助作川) と火防線の氾濫により城 西・城南地区の 10 町で浸水被害があった。城南地区の浸水は、助作



図9 助作川、旧四ツ屋川による水害の事例（著者作成）



図10 助作川、奥田用水による水害の事例（著者作成）
川の溢水が背割り水路を逆流したものと考えられる。さらに臿川も 5 尺に増水し、右岸の 6 町で浸水被害があった ${ }^{36)}$ 。左岸が無事なこ とから、鼬川よりも奥田用水の汇濫が疑われる。なお、奥田用水は



\section{7. 考察一水害の背景と水路の治水機能 \\ (1) 平常時の課題}

扇状地は河川の堆積によって形成される氾濫原であり、砂㗂質で 保水性に乏しく稲作には適さないが、水を掛け流せばその久点を補 うことができる。一般には本流を堤防で固定し、派川群を用水路と して水門で流量を制御しながら、流域を灌溉する。

常願寺川扇状地でも中世以降、派川沿いの洪水が少ない土地、湧 水が豊富な土地から開発が進み、太田保と呼ばれる荘園が形成され ていた。天正 8 (1580) 年に藩主佐々成政が扇頂部に堤防（佐々堤） を築いて以降、洪水の多い常願寺川の本流沿いでも新田開発が始ま り、宝永 6 (1709) 年には左岸に 12 用水が存在している ${ }^{37)}$

扇状地の扇頂部で浸透した伏流水は扇端部で浸出する。水に恵ま れない扇央部に農業用水をめぐらせた結果、扇端部に発する四ツ屋 川、冷川、助作川などの小河川では自然の湧水に農業用水が加わり、 下流の富山町に過剩な水量をもたらす。

\section{(2) 洪水時の課題}

扇状地河川における治水の要は扇頂部である。山間峡谷の急流が ここで解放されるため破堤しやすく、出水は扇状地河川を伝って扇 面に拡がる。常願寺川でも扇頂部馬瀬口の出水は、左岸最大の派川 である鼠川を流下し、富山町を直撃する。このため、扇頂部には上 述の佐々堤はじめ、幾重もの堤防や水害防備林がつくられた。

一方、農業用水を扇状地の隅々まで送るには高い地点で取水する 必要があり、12 用水のうち半数の取水口が扇頂部に集中していた。 明治 24 年の大水害直後、現地を調查した内務省技術顧問デ・レーケ は、取水が洪水を誘引し、堤防の機能を阻害していると指摘する。 すなわち、鼠川の水害は扇状地の新田開発がもたらした人災の性格 が強い。この問題は全用水路を一系統にまとめ、上流の山間部から 取水する常西合口用水の完成まで解決されなかった ${ }^{38)}$ 。

\section{（3）近世富山町の洪水対策}

近世富山町の水害を大別すると、 ( a ) 神通川の堤防が決壊し城西、 城南地区が浸水、（b ) 鼠川が氾濫し城東地区が浸水、（c ）扇状地河 川が氾濫し城南地区が浸水、の 3 類型がある ${ }^{39)}$ 。助作川は ( a )、鼠 川支流は ( b )、南堀は ( c )を防げないまでも緩和することができる。 また、洪水がピークを過ぎれば、水路網が排水機能を発揮するため、 浸透性の高い砂㗂質の土地と相まって湛水時間は短い。圧倒的な破 壊力を持つ神通川や常願寺川に対し、強力な治水手段を持たない近 世には、水害の予防より減災をめざすしかなく、城下の水路網も浸 水の範囲や時間を限定する役割を担ったものと考えられる。

平常時においても、南堀は過剩な水量を制御するために重要な水 路である。もともとは富山城下を流れていた小河川を東西に振り分 け、町外に排除する迁回路として開削された。

\section{(4) 扇状地の内水氾濫}

明治 26 年完成の常西合口用水によって (b ) 鼠川の水害が、大正 12 年完成の馳越線によって (a ) 神通川の水害が減少すると、その陰 に隠れていた ( c ) 扇状地河川の水害が顕在化した。これは扇状地の 
降水量や小河川の流量に対し、南堀による排水量が追いつかない「扇 状地の内水氾濫」と考えられる。

その場合、南堀がなかった正保期以前の状況が再現され、城西地 区では助作川、城南地区では旧四ツ屋川や旧泠川の河道に沿った各 町が浸水する。正保図には描かれていないが、鼠川右岸の奥田用水 も旧派川の河道を利用して作られた可能性が高く、鼠川が増水寸れ ば流れが復活する。これらが図 9、図 10 でみた水害のメカニズムだ が、こうした水害は戦後の小河川整備によって徐々に減少した。

\section{(5) 城下の内水汇濫}

近年は城下に降った雨水量が、排水路の容量を超えて起きる「城 下の内水氾濫」が問題になっている。平成 20 年 8 月に中心部の大型 商業施設などで起きた浸水被害は、局地豪雨や建築構造が主因だが、 地区の排水能力も不足していた ${ }^{40)}$ 。当該施設は図 8 の A 2 水路の南 側にあり、埋め立て前は遊水池として機能した城涼にも近い。水路 の暗渠化による排水能力の変化については定量的な検討が必要だが、 少なくとも溢水の余地がある開渠に比べて硬直的なシステムになっ たと考えられる。

なお、中心市街地の排水能力向上のため、暗渠が老朽化した火防 水路を再整備し、雨水排水路として活用寸る試みが始まっている ${ }^{41}$ 。

\section{8. まとめ}

常願寺川扇状地の端部、神通川の河畔に立地する富山城下町は、 良質で豊かな水に恵まれる一方、近世、近代を通じて水害に苦しん できた。これを背景に、都市史では城下町、産業史では灌涀農業、 土木史では近代治水事業の研究が蓄積されてきたが、それらの相互 関係が論じられることはなかった。

本研究では水路網の形成過程、仕組み、水害の分析を通じて次の 3 点を明らかにした。第一に富山藩は上流の後背農地には豊かな水 を確保しつつ、下流の城下からは過剩な水を排除するという困難な 課題に直面し、第二に城下の扇状地河川群を迂回させ、旧河道を排 水幹線として、それに背割り水路を集める排水路網を構築した。第 三に扇状地河川群の水量が迁回水路の容量を超えると、城下の旧河 道に流入し、背割り水路を逆流して浸水被害が拡大寸る。昭和期に 水路の暗渠化、埋め戻しが進んだ事情は今後解明したい。

近世都市において多面的な機能を有した水路は、産業や生活、環 境や景観など多様な観点から研究されてきたが、一事例ながら新た に治水機能の重要性を示すことができたと考える。

\section{謝辞}

本研究は科学研究費補助金基盤研究 (S)（代表 : 陣内秀信）「水都 に関する歴史と環境の視点からの比較研究」の成果の一部である。

\section{参考文献}

1）渡部一二：生きている水路一その構造と魅力、東海大学出版会、1984.8 2) 佐々木邦博ほか: 長野市松代町の城下絵図に見られる水路システムの特徵、 ランドスケープ研究、67 巻 5 号、pp. 369-374、日本造園学会、2004

3) 玉井信行ほか: 城下町金沢の河川 - 用水の整備、城下町金沢学術研究 1 、 第 2 分冊、金沢市、2010.3

4）後藤隆太郎ほか: 沖積低平地に立地する城下町都市佐賀における水路の空 間特性に関寸る考察、日本建築学会計画系論文集、第 573 号、pp. 93-100、 2003. 11

5）田中尚人ほか: 祇園白川地区における都市形成と白川・琵琶湖疏水の役割
に関する史的研究、土木学会論文集、No. 681/IV-52、pp. 77-86、2001.7 6) 田中尚人ほか: 舟運を基軸とした京都高瀬川沿川の都市形成に関する研究、 土木計画学研究・論文集、第 17 号、pp. 491-496、2000.9

7）中岡義介: 水辺のデザイン一水辺型生活空間の創造、森北出版、pp. 51-58、 1986. 12

8）中岡義介：前掲書、pp. 58-61

9) 水田恒樹：近世・近代における富山藩領の土地利用と治水に関する研究、 日本建築学会計画系論文集、第 676 号、pp. 1531-1536、2012.6

10）阪口豊ほか：日本の川、岩波書店、pp. 126-133、1986.3

11）重杉俊雄：神通川誌、富山漁業協同組合、pp. 32-37、1955

12）久保尚文：越中中世史の研究、pp403-419、桂書房、1983.4

13）古川知明 : 中世富山城の考古学的調査に基づく考察、富山史檀、 $142 \cdot 143$ 合併号、pp. 50-59、越中史壇会、2004.3

14）高瀬保：近世の富山城下町、富山史壇、61 号、pp. 19-31、越中史壇会、 1976

15）金沢市立玉川図書館蔵

16）古川知明：鼠川と富山城下町一絵図からみた近世前期の河道復元一、富 山史壇、第 152 号、pp. 1-11、越中史壇会、2007.5

17）星井町小学校教育百年史編集委員会 : 教育百年史、p. 9、星井町小学校教 育百周年記念実行委員会、1974. 6

18）古川知明：慶長期富山城と城下町構造、富山史壇、第 150 号、越中史壇 会、2006

19）富山県立図書館 : 古絵図・貴重書ギャラリー、古絵図・富山城下町絵図、 御調理富山絵図 [T092. 93-105]

20）富山市郷土博物館蔵：「富山市実測全図」中田書店、1892.9、など

21）藤岡謙二郎編：城下町とその変貌、金田章裕、「富山」、pp.94-98、柳原 書店、1983.10

22）富山市史編さん委員会編：富山市史・通史＜下巻＞、pp. 17-20、1987. 1

23）富山市史編さん委員会編：前掲書、pp. 287-288

24）国立公文書館デジタルアーカイブ：富山都市計画防火水路及同事業並其 ノ執行年度決定ノ件、公文雑纂・昭和 13 年・第 70 巻・都市計画 19、pp. 15-20

25）古川知明ほか: 富山城下町絵図の変遷と発掘調査による検証、富山史壇、 第 155 号、越中史壇会、p. 8、2008

26）古川知明ほか：(参考文献 25)、p. 5

27）深井甚三：近世城下町富山の建設 - 再建と地域構造、富山大学教育学部 紀要 A (文科系)、No. 40、pp. 1-13、1992

28）田中喜男：城下町富山の町民とくらし、pp. 266-269、高科書店、1993.5

29）富山県立図書館: 古絵図・貴重書ギャラリー、古絵図・富山城下町絵図、 越中富山御城下絵図 [T092. 93-106]、富山御城下絵図 [内 399]など

30）玉井信行ほか：前掲書、p. 39

31）富山県立図書館: 古絵図・貴重書ギャラリー、古絵図・富山城下町絵図、 鼠川の図 [T092. 93-104]

32）島原義三郎ほか編 : 鼠(いたち)川の記憶、pp. 42-45、桂書房、2004

33）堀川校下ふるさとづくり推進協議会編：わたしたちの町堀川「寺院・地 蔵尊そしていたち川」、pp. 51-52、私家版、2010

34）田中喜男：前掲書、pp. 113-115

35）富山地方気象台：富山県気象災異誌、日本気象協会富山支部、1971.3

36）富山市史編集委員会編：富山市史、第 2 巻、pp. 478-479、1960. 4

37) 水田恒樹：前掲

38）水田恒樹：前掲

39）水田恒樹：前掲

40）読売新聞：争点 09 市長・市議選 (6)、ゲリラ豪雨対策一排水力の向上急 務、2009.4.9 朝刊・富山版

41）北日本新聞 : 新年度・冠水被害防止へ対策 - 富山市、2009.2.26 朝刊 